\title{
Hemodynamic Effects of
}

\section{Phenoxybenzamine in Anesthetized Dogs}

\author{
Noble O. Fowler, John C. Holmes, Thomas E. Gaffney, Philip J. Privitera, and \\ GUNTER GruPP
}

\author{
From the Cardiac Research Laboratory, Division of Cardiology, and Division of \\ Clinical Pharmacology, Department of Medicine, University of Cincinnati \\ College of Medicine, Cincinnati, Ohio 45229
}

\begin{abstract}
A B S T R A C T Our studies demonstrated that phenoxybenzamine, $10 \mathrm{mg} / \mathrm{kg}$, administered intravenously to intact anesthetized dogs, produced an immediate and significant increase of heart rate and cardiac output. In heart-lung preparations, phenoxybenzamine had no effect or a negative cardiac inotropic effect, hence these actions were not related to direct cardiac action or to release of myocardial norepinephrine stores. Serial estimations of arterial blood catecholamines after phenoxybenzamine showed an increase of epinephrine and norepinephrine; the peak values of these catecholamines did not correlate well with the maximum cardiac output responses. Ganglionic blockade largely eliminated the early cardiac effects of phenoxybenzamine, hence its action did not appear to be upon peripheral terminals of postganglionic sympathetic or parasympathetic nerves. Phenoxybenzamine was found to have antivagal actions which might account for some of the delayed cardiac acceleration. When beta adrenergic receptor blockade was induced by sotalol, the cardiac effects of phenoxybenzamine were largely eliminated. Baroreceptor denervation prevented the increase of cardiac output after phenoxybenzamine. These observations are consistent with the concept that the increase of cardiac rate and output produced by phenoxybenzamine is principally mediated by baroreceptor reflexes acting through sympathetic cardiac nerves or circulating catecholamines.
\end{abstract}

\section{INTRODUCTION}

Phenoxybenzamine, an alpha adrenergic receptor blocking agent, is known to increase the cardiac output and stroke volume (1) and renal blood flow (2) when given intravenously to dogs with experimental shock. In a recent study, we found that intravenous phenoxybenza-

Received for publication 26 March 1970 and in revised form 30 June 1970. mine increased the cardiac stroke volume, heart rate, and cardiac output of dogs during experimental cardiac tamponade (3). Aviado (4) stated that alpha receptor blocking drugs induce cardiac stimulation mostly because the fall in systemic blood pressure accompanying systemic vasodilation initiates reflex tachycardia. However, no studies of intact animals were described. Nickerson found that the myocardial effects of direct or reflex sympathetic nerve stimulation were not inhibited by dibenamine and other alpha adrenergic blocking atents (5). Nickerson stated that phenoxybenzamine commonly produces a moderate increase in cardiac output and a decrease in total peripheral resistance in normal recumbent subjects, but no data were presented (6).

In the only published study of the cardiac output of intact animals that we have been able to find, Mills and Moyer reported a decrease in cardiac output of dogs given phenoxybenzamine, $10 \mathrm{mg} / \mathrm{kg}$ intravenously (7). Since these results appeared to conflict with the observations cited above, we decided to investigate the hemodynamic effects of phenoxybenzamine in the intact anesthetized animal. The studies to be described showed that phenoxybenzamine did increase the cardiac output in intact dogs. The mechanism of this response was then examined in animals undergoing ganglionic blockade, in animals during beta adrènergic receptor blockade, and in the dog heart-lung preparation in which presumably neither central nor ganglionic sympathetic activity is present. Blood catecholamine levels were measured in some experiments and vagal nerve stimulation frequency-response curve were evaluated in others. Some animals were studied after baroreceptor denervation.

\section{METHODS}

Dogs were studied under morphine-chloralose anesthesia. The animals each weighed approximately $20 \mathrm{~kg}$, and each 
received heparin, $5000 \mathrm{U}$ intravenously. The animals were anesthetized with morphine, $3 \mathrm{mg} / \mathrm{kg}$ intravenously or $5 \mathrm{mg} /$ $\mathrm{kg}$ intraperitoneally, followed by chloralose, $70 \mathrm{mg} / \mathrm{kg}$ body weight intravenously. In the open chest animals used for heart-lung preparations, the dose of chloralose was 105 $\mathrm{mg} / \mathrm{kg}$. Cardiac outputs were measured by right atrial injection of $2.5 \mathrm{mg}$ of indocyanine green dye through a Cournand catheter. Arterial blood was sampled by means of a Colson constant withdrawal syringe (The Colson Company, Chicago, Ill.) at a rate of $38 \mathrm{ml} / \mathrm{min}$ through a Cournand catheter inserted into the ascending aorta. Changes in blood optical density were estimated by a Gilford (Model 103) densitometer (Gilford Instrument Labs, Inc., Oberlin, Ohio) as recorded with a Texas Instruments Inc., strip chart recorder (Dallas, Tex.). Respiration was supported with $100 \% \quad \mathrm{O}_{2}$ delivered through an endotracheal tube by a Harvard respirator (Harvard Apparatus Co., Millis, Mass.) set at a rate and stroke volume to maintain normal arterial $\mathrm{pH}$. With each measurement of cardiac output, right atrial and aortic pressures were determined with Statham P23dB gauges (Statham Instruments, Inc., Los Angeles, Calif.) as recorded upon a Hewlett-Packard four-channel direct-writing oscillograph (Hewlett-Packard Co., Palo Alto, Calif.). The heart rate was determined from the phasic aortic pressure. With each cardiac output determination, arterial blood $\mathrm{pH}$, arterial oxygen saturation, and rectal temperature were measured. Except in group I and group VII animals, the criteria for acceptable experiments were that arterial $\mathrm{pH}$ was always between 7.35 and 7.45 ; arterial oxygen saturation was always above $95 \%$ of capacity, and rectal temperature varied no more than $1^{\circ} \mathrm{C}$. In group I, systemic arterial oxygen saturation was no lower than $89 \%$ of capacity; arterial blood $\mathrm{pH}$ was between 7.34 and 7.45 ; rectal temperatures were not measured in this group. In group VII systemic arterial oxygen saturation was no lower than $85 \%$ of capacity; arterial blood $\mathrm{pH}$ and rectal temperatures were controlled as in groups II through VI. Seven groups of animals were studied.

Group I. (a) The hemodynamic effects of phenoxybenzamine, $10 \mathrm{mg} / \mathrm{kg}$ intravenously, were investigated in eight dogs. Norepinephrine, 1 or $5 \mu \mathrm{g} / \mathrm{kg}$, was administered as an intravenous bolus before phenoxybenzamine and at the end of the experiment to evaluate the efficacy of alpha blockade in preventing arterial blood pressure rise. Phenoxybenzamine was given at a rate of $2 \mathrm{mg} / \mathrm{kg}$ per min over a period of $5 \mathrm{~min}$. Hemodynamic measurements were made in a control period before phenoxybenzamine, immediately after phenoxybenzamine, and $10 \mathrm{~min}$ after phenoxybenzamine.

(b) The hemodynamic effects of phenoxybenzamine, 5 $\mathrm{mg} / \mathrm{kg}$, given intravenously in $5 \mathrm{~min}$ were studied in six open chest dogs. In these animals, respirations were supported by a Harvard respirator which employed $100 \%$ oxygen. In addition to systemic blood and cardiac output, left atrial mean pressure was measured as an estimate of left ventricular filling pressure.

Group II. Arterial plasma catecholamines were measured in four additional animals. The animals were prepared and investigated as in group I, except that arterial plasma catecholamines were measured in six periods. There were two control periods; the third period was selected during the phenoxybenzamine injection as soon as a positive chronotropic effect was observed. The fourth period was immediately after completion of the phenoxybenzamine administration. The fifth and sixth periods were selected from the following three: the 5-, 10-, and $30-\mathrm{min}$ periods after phenoxybenza- mine. The blood sample from the period showing the least rise in cardiac output was discarded and catecholamine analysis was performed upon the remaining two. Because of the large volume of blood required for the catecholamine studies $(20 \mathrm{ml}$ for each sample) $(8,9)$, the blood removed from the experimental animal was replaced with matched donor dog's blood.

Group III. The hemodynamic effects of phenoxybenzamine were studied in six animals after sotalol (MJ-1999)induced beta adrenergic blockade. The animals were investigated as in group I, except that beta adrenergic blockade was induced by sotalol, ${ }^{1} 5 \mathrm{mg} / \mathrm{kg}$ intravenously. The efficacy of beta blockade was evaluated by the heart rate response to isoproterenol, $0.5 \mu \mathrm{g} / \mathrm{kg}$ intravenously given before sotalol, $5 \mathrm{~min}$ after sotalol, and at the end of the experiments. $5 \mathrm{~min}$ after sotalol, the heart rate increase with isoproterenol was either completely blocked or rose at most $3 \%$ of the increase before sotalol. At the end of the experiments, the heart rate response to isoproterenol was found to be blocked by $98,93,92,92,91$, and $78 \%$ when compared to the rate increase before sotalol in the six respective animals.

Group IV. The hemodynamic effects of phenoxybenzamine were evaluated in six animals after autonomic ganglionic blockade. The animals were prepared as in group I. Ganglionic blockade was induced with hexamethonium, 10 $\mathrm{mg} / \mathrm{kg}$ intravenously followed by atropine, $1 \mathrm{mg} / \mathrm{kg}$ intravenously (10). The efficacy of hexamethonium-induced ganglionic blockade was tested by observing the heart rate response to stimulation of the peripheral end of the sectioned right vagus nerve in the neck before hexamethonium and then after hexamethonium but before atropine was given. The ganglionic blockade was effective in all animals as judged by the complete prevention of the negative chronotropic effect of vagal stimulation in each animal. The left vagus was sectioned before stimulating the right vagus. The right vagus was stimulated with $1-\mathrm{msec}$ impulses at supramaximal voltage with frequencies of 1,3 , and 10 cycles/sec by means of a Grass S-4 stimulator (Grass Instrument Co., Quincy, Mass.).

Group $V$. The vagal effects of phenoxybenzamine were studied in six animals that received the drug and in three control animals. The animals were prepared as in group I. The peripheral end of the right vagus nerve was stimulated at supramaximal voltage with 1 -msec stimuli and at 1,3 , 10 , and $30 \mathrm{cycles} / \mathrm{sec}$. The heart rate response was evaluated with an electrocardiogram so that the atrial rate might be determined. The order of application of stimulus frequency was randomized. The frequency-response curve was determined before and after phenoxybenzamine, $10 \mathrm{mg} / \mathrm{kg}$ intravenously. The control animals received only the vehicle, which consisted of $3 \mathrm{ml}$ of absolute alcohol and $47 \mathrm{ml}$ of physiologic saline.

(b) In five dogs, the effects of peripheral right vagal nerve stimulation were similarly examined in three periods; control, during cardiac acceleration produced by intravenous isoproterenol infusion, 3.06 or $7.64 \mu \mathrm{g} / \mathrm{min}$, and after phenoxybenzamine $10 \mathrm{mg} / \mathrm{kg}$ intravenously. Supramaximal, 1 -msec stimuli were employed; the frequencies were 1,10 , and 30 cycles/sec.

Group VI. The cardiac effects of phenoxybenzamine were evaluated in six Starling dog heart-lung preparations. The dogs weighed $18-26 \mathrm{~kg}$. The Starling resistance was set at $90 \mathrm{~mm} \mathrm{Hg}$. The venous reservoir was adjusted so as to

\footnotetext{
${ }^{1}$ Kindly supplied by the Mead Johnson \& Co., Evansville, Ind.
} 
yield a control cardiac output of $900-1250 \mathrm{ml} / \mathrm{min}$ as determined by the Stohlnikoff stromuhr. Left atrial pressure and arterial blood pressure were measured by Statham gauges (Statham Instruments, Inc., Los Angeles, Calif.). Left ventricular force was measured with Walton-Brodie strain gauge arches (Warren E. Collins, Inc., Braintree, Mass). Blood temperature, measured from the right atrium, was controlled between $36.8^{\circ}$ and $39^{\circ} \mathrm{C}$ by a heatedjacket blood reservoir, except in one animal, in which the temperature range was $35.4^{\circ}-36.2^{\circ} \mathrm{C}$. Blood $\mathrm{pH}$ was controlled between 7.35 and 7.45. Arterial oxygen saturation was always above $95 \%$ of capacity. The phenoxybenzamine was dissolved in a vehicle of $3 \mathrm{ml}$ of absolute ethanol and $47 \mathrm{ml}$ of physiologic saline for $5 \mathrm{mg} / \mathrm{kg}$ doses and in 0.6 $\mathrm{ml}$ of alcohol and $49.4 \mathrm{ml}$ of saline for $1 \mathrm{mg} / \mathrm{kg}$ doses. In two animals, $1 \mathrm{mg} / \mathrm{kg}$ of phenoxybenzamine was given. In four animals, a total of $5 \mathrm{mg} / \mathrm{kg}$ of phenoxybenzamine was given in divided doses of $1 \mathrm{mg} / \mathrm{kg}$ at intervals of $2 \mathrm{~min}$. Cardiac outputs and pressures were determined after each dose. In each experiment the effect of the vehicle was also tested in like manner. The vehicle preceded the phenoxybenzamine in half the experiments and followed it in the others.

Group VII. The hemodynamic effects of phenoxybenzamine, $10 \mathrm{mg} / \mathrm{kg}$ intravenously, were evaluated in five dogs after baroreceptor denervation. The animals were given morphine chloralose anesthesia, and respiration was maintained by a Harvard respirator and ambient air. Cardiac outputs, arterial blood pressure, and heart rates were measured in a control period, after baroreceptor denervation, and after phenoxybenzamine at the following time intervals: immediate; $5 \mathrm{~min}$; $10 \mathrm{~min}$; and $20 \mathrm{~min}$. Baroreceptor and carotid body chemoreceptor denervation was accomplished by a bilateral division of the nerve of Hering and of all visible nerves supplying the carotid sinus. The afferent pathway from the aortic arch was divided by means of bilateral cervical vagal section. The adequacy of carotid sinus denervation was demonstrated by failure of the arterial blood pressure and heart rate to rise significantly during unilateral and bilateral common carotid artery occlusion. Before denervation of the carotid sinus, systolic arterial blood pressure rose $96-125 \mathrm{~mm} \mathrm{Hg}$ in response to bilateral carotid occlusion. After denervation, the systolic blood pressure change was minus 5 tó plus $18 \mathrm{~mm} \mathrm{Hg}$ in the five animals.

\section{RESULTS}

Group I. (a) The effects of phenoxybenzamine, 10 $\mathrm{mg} / \mathrm{kg}$ administered intravenously in $5 \mathrm{~min}$, upon heart rate and cardiac output of eight dogs are summarized in Figs. 1 and 2 and in Table I. The average heart rates in the two control periods were $82.9 \pm 11.2$ (s.e.), and $87.8 \pm 11.2$ beats $/$ min (Fig. 1). Immediately after phenoxybenzamine, the average heart rate was $196.5 \pm 18.9$ beats $/ \mathrm{min}, P<0.001$. $10 \mathrm{~min}$ after phenoxybenzamine, the average heart rate was $189.8 \pm 21.4$ beats $/ \mathrm{min}, P<$

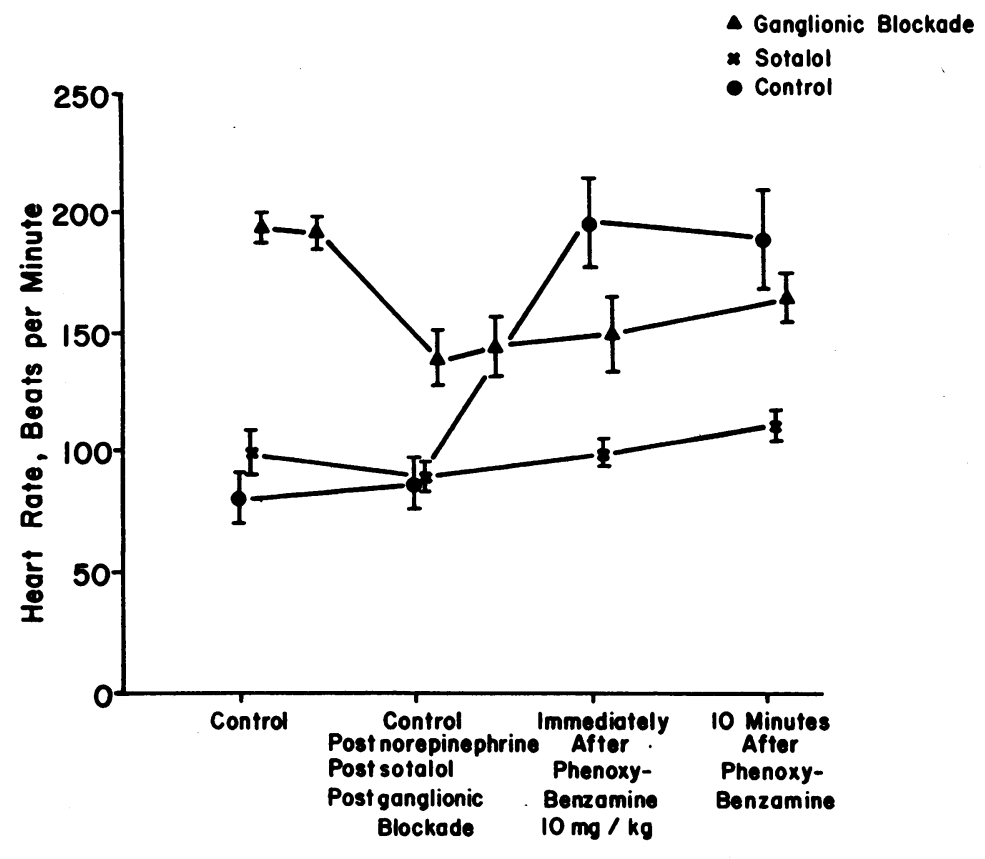

FiguRe 1 Effect of phenoxybenzamine, $10 \mathrm{mg} / \mathrm{kg}$ intravenously upon heart rate in the following three groups of animals: controls; animals with beta adrenergic receptor blockade. The centers of the vertical bars represent means; the termini of these bars represent the limit of 1 SE from the mean. Norepinephrine, $5 \mathrm{mg} / \mathrm{kg}$ intravenously, was given between the first and second control measurements to establish a base line for the later demonstration of effective alpha adrenergic blockade. The effects of norepinephrine upon heart rate and blood pressure subsided within 3-5 min, when the second control measurements were made. 


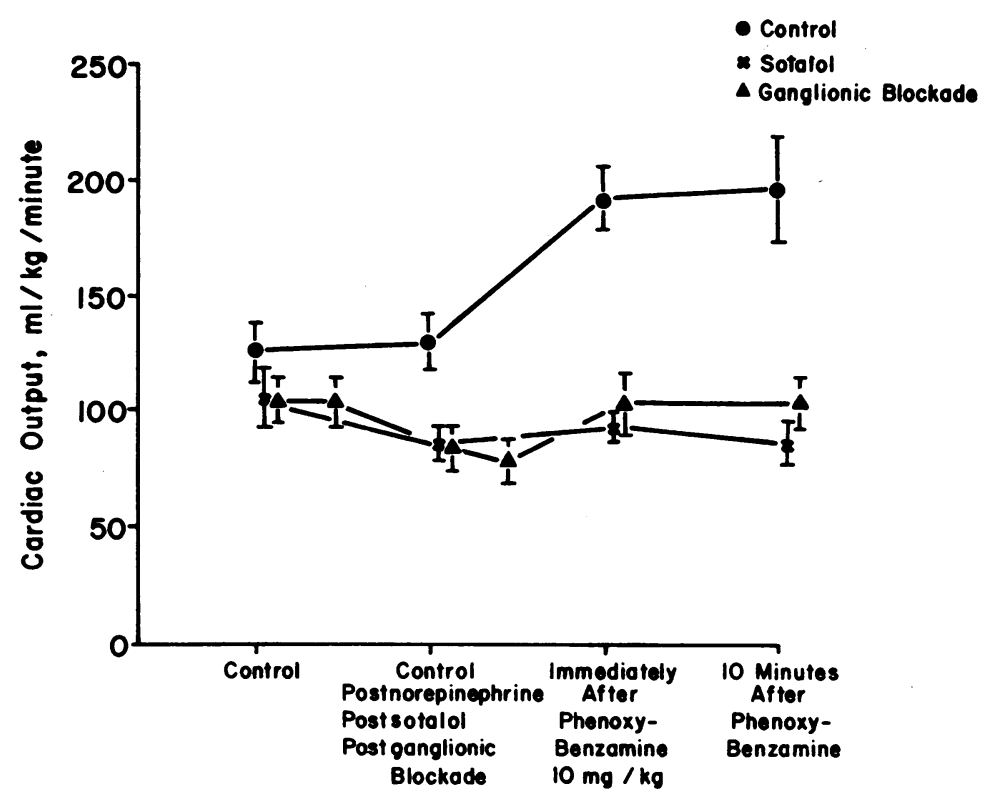

FIGURE 2 Effect of phenoxybenzamine, $10 \mathrm{mg} / \mathrm{kg}$ intravenously upon cardiac output in the following three groups of animals: controls; animals with autonomic ganglionic blockade; and animals with beta adrenergic receptor blockade. Norepinephrine, $5 \mathrm{mg} / \mathrm{kg}$ intravenously, was given between the first and second control measurements to establish a base line for the later demonstration of effective alpha adrenergic blockade. The effects of norepinephrine upon heart rate and blood pressure subsided within 3-5 min, when the second control measurements were made.

0.01. Immediately after phenoxybenzamine, mean systolic blood pressure fell from 167 to $139.3 \mathrm{~mm} \mathrm{Hg}, P<$ 0.001. $10 \mathrm{~min}$ after phenoxybenzamine, mean systolic pressure was $136.6 \mathrm{~mm} \mathrm{Hg}, P<0.02$. The degree of alpha adrenergic blockade judged by the decrease of systolic pressure rise to intravenous norepinephrine was $50,62,73,79,82,93,100$, and $100 \%$ in the respective eight animals. The averages of cardiac outputs in the two control periods were $126.6 \pm 12.3$ and 131.7 $\pm 12.4 \mathrm{ml} / \mathrm{kg}$ per min (Table I, Fig. 2). Immediately after phenoxybenzamine, the average cardiac output had increased to $193.4 \pm 13.8 \mathrm{ml} / \mathrm{kg}$ per $\min , P<0.001 .10$ min after phenoxybenzamine, the average cardiac output was $197.8 \pm 24 \mathrm{ml} / \mathrm{kg}$ per $\mathrm{min}, P<0.05$. The average of right atrial pressures showed little change after phenoxybenzamine (Table I).

(b) The hemodynamic changes produced by administration of phenoxybenzamine $5 \mathrm{mg} / \mathrm{kg}$ intravenously are summarized in Table II. The cardiac output increased significantly immediately after phenoxybenzamine and was significantly elevated $10 \mathrm{~min}$ after phenoxybenzamine (Table II). The heart rate was significantly increased over the control value at the same times, and the systolic arterial pressure was significantly lower ( $\mathrm{Ta}$ ble II). The unexpected increase in systolic blood pres- sure of dog No. $149810 \mathrm{~min}$ after phenoxybenzamine was associated with a fall in diastolic pressure and a striking increase of cardiac output. The mean left atrial pressure showed little change immediately after phenoxybenzamine with a slight tendency to decrease $10 \mathrm{~min}$ later.

Group II. The relationship between arterial blood catecholamines and the level of cardiac output is shown in Figs. 3 and 4. Control values for epinephrine and norepinephrine were below $1 \mu \mathrm{g} /$ liter in each animal. After $10 \mathrm{mg}$ of phenoxybenzamine intravenously, arterial blood epinephrine and norepinephrine values rose in each animal, but there was no consistent relationship between the change in cardiac output and the level of arterial blood epinephrine or norepinephrnie (Fig. 3). The group relationship between systolic arterial pressure, arterial blood epinephrine and norepinephrine levels, heart rate, and cardiac output and right atrial mean pressure is shown in Fig. 4.

Group III. Beta adrenergic receptor blockade was induced by sotalol in six animals before giving phenoxybenzamine, $10 \mathrm{mg} / \mathrm{kg}$ intravenously. The mean systolic blood pressure immediately after phenoxybenzamine (108.3 $\mathrm{mm} \mathrm{Hg}$ ) was $24.2 \mathrm{~mm} \mathrm{Hg}$ below that after sotalol (132.5 mm Hg), $P<0.01$ (Table I). The mean systolic 
TABLE I

Effects of Phenoxybenzamine upon Hemodynamics

\begin{tabular}{|c|c|c|c|c|c|c|c|c|}
\hline \multirow[b]{2}{*}{$\begin{array}{l}\text { Dog } \\
\text { No. }\end{array}$} & \multirow[b]{2}{*}{ Weight } & \multicolumn{4}{|c|}{ Cardiac output } & \multicolumn{3}{|c|}{ Heart rate } \\
\hline & & \multicolumn{2}{|c|}{ Control } & $\begin{array}{c}\text { Immed. after } \\
\text { phenoxy- } \\
\text { benzamine }\end{array}$ & $\begin{array}{c}10 \text { min after } \\
\text { phenoxy- } \\
\text { benzamine }\end{array}$ & \multicolumn{2}{|l|}{ Control } & $\begin{array}{c}\text { Immed. after } \\
\text { phenoxy- } \\
\text { benzamine }\end{array}$ \\
\hline & kg & \multicolumn{4}{|c|}{$m l / k g$ per $\min$} & \multicolumn{3}{|c|}{ beats/min } \\
\hline \multicolumn{9}{|c|}{ a. Intact animals } \\
\hline 1482 & 27.3 & 90.5 & 94.5 & 143.6 & 125.7 & 66 & 66 & 162 \\
\hline 1483 & 25 & 89.7 & 94 & 137.5 & 143.9 & 90 & 84 & 252 \\
\hline 1484 & 24 & 147.3 & 150.4 & 217 & 180 & 78 & 84 & 210 \\
\hline 1524 & 19.8 & 191.8 & 191.8 & 236.3 & 193.5 & 156 & 162 & 252 \\
\hline 1527 & 20.5 & 110.9 & 145.5 & 193.6 & 149.9 & 63 & 69 & 252 \\
\hline 1529 & 22.3 & 121.5 & 133 & 168.2 & 216.9 & 84 & 96 & 186 \\
\hline 1531 & 16.4 & 151.3 & 149.1 & 230.8 & 339 & 69 & 72 & 138 \\
\hline 1533 & 20 & 109.9 & 95.4 & 219.8 & 233.4 & 57 & 69 & 120 \\
\hline \multicolumn{2}{|c|}{ Mean \pm SE } & $126.6 \pm 12.3$ & $131.7 \pm 12.4$ & $193.4 \pm 13.8$ & $197.8 \pm 24$ & $82.9 \pm 11.2$ & $87.8 \pm 11.2$ & $196.5 \pm 18.9$ \\
\hline \multicolumn{4}{|c|}{$\begin{array}{l}\text { Significance of change } \\
\text { from control }\end{array}$} & $P<0.001$ & $P<0.05$ & & & $P<0.001$ \\
\hline \multicolumn{9}{|c|}{ b. Sotalol, beta adrenergic blockade animals (group III) } \\
\hline 1640 & 20.9 & 107.1 & $70.5 \ddagger$ & 86.9 & 67.7 & 102 & $84 \ddagger$ & 96 \\
\hline 1642 & 21.1 & 132.7 & $84.8 \ddagger$ & 71.8 & 85.9 & 99 & $96 \ddagger$ & 90 \\
\hline 1644 & 18.6 & 126 & $116.7 \ddagger$ & 115.8 & 108.5 & 114 & $96 \ddagger$ & 120 \\
\hline 1650 & 18.2 & 124 & $94.5 \ddagger$ & 102.1 & 94.1 & 126 & $114 \ddagger$ & 114 \\
\hline 1652 & 23.1 & 91 & $63.9 \ddagger$ & 88.1 & 65.2 & 104 & $78 \ddagger$ & 96 \\
\hline 1660 & 24.3 & 56 & $97.4 \ddagger$ & 103.7 & 110.7 & 60 & $84 \ddagger$ & 90 \\
\hline $\mathrm{Me}$ & & $106.1 \pm 11.8$ & $88 \ddagger \pm 7.9$ & $94.7 \pm 6.4$ & $88.7 \pm 8.0$ & $101 \pm 9.1$ & $92 \ddagger \pm 5.3$ & $101 \pm 5.2$ \\
\hline Sig & $\begin{array}{l}\text { ce of } c \\
\text { ontrol }\end{array}$ & $P_{i}>0.2$ & & $P>0.2$ & $P>0.8$ & $P>$ & & $P>0.1$ \\
\hline
\end{tabular}

* Average of systolic arterial blood pressures.

$\ddagger$ Indicates control value after sotalol $5 \mathrm{mg} / \mathrm{kg}$ intravenously.

blood pressure $10 \mathrm{~min}$ after phenoxybenzamine was 98.2 $\mathrm{mm} \mathrm{Hg}$, or $34.3 \mathrm{~mm} \mathrm{Hg}$ below the postsotalol value, $P<$ 0.01 . The heart rate responses to phenoxybenzamine are shown in Fig. 1 and Table I. The average heart rate in the control period was $101 \pm 9.1$ beats $/ \mathrm{min}$. After sotalol, the mean heart rate was $92 \pm 5.3$ beats $/ \mathrm{min}, P>0.2$. Immediately after phenoxybenzamine, the average heart rate was $101 \pm 5.2$ beats $/ \mathrm{min}, P>0.1 .10 \mathrm{~min}$ after phenoxybenzamine, the average heart rate was $112 \pm 6.8$ beats $/ \mathrm{min}, P<0.02$. The increase above the postsotalol heart rate was significant. The cardiac output responses to phenoxybenzamine after sotalol are illustrated in Fig.
2. The average control cardiac output was $106.1 \pm 11.8$ $\mathrm{ml} / \mathrm{kg}$ per min. After sotalol, the average cardiac output was $88 \pm 7.9 \mathrm{ml} / \mathrm{kg}$ per min, $P>0.2$. Immediately after phenoxybenzamine, the average cardiac output was $94.7 \pm 6.4 \mathrm{ml} / \mathrm{kg}$ per min, $P>0.2 .10 \mathrm{~min}$ after phenoxybenzamine, the average cardiac output was $88.7 \pm 8.0$ $\mathrm{ml} / \mathrm{kg}$ per min, $P>0.8$. The mean right atrial pressure showed little change after sotalol or phenoxybenzamine (Table I).

Group IV. The hemodynamic effects of phenoxybenzamine, $10 \mathrm{mg} / \mathrm{kg}$ given intravenously after ganglionic blockade, were studied in six animals and the re- 
in Closed-Chest Dogs (Group 1a)

\begin{tabular}{|c|c|c|c|c|c|c|c|}
\hline \multirow{2}{*}{ 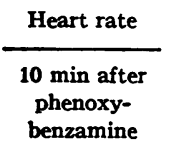 } & \multicolumn{3}{|c|}{ Arterial blood pressure } & \multicolumn{4}{|c|}{ Right atrial mean pressure } \\
\hline & Control & $\begin{array}{c}\text { Immed. after } \\
\text { phenoxy- } \\
\text { benzamine }\end{array}$ & $\begin{array}{l}10 \text { min after } \\
\text { phenoxy- } \\
\text { benzamine }\end{array}$ & Control & & $\begin{array}{c}\text { Immed. after } \\
\text { phenoxy- } \\
\text { benzamine }\end{array}$ & $\begin{array}{l}10 \text { min after } \\
\text { phenoxy- } \\
\text { benzamine }\end{array}$ \\
\hline beats/min & \multicolumn{3}{|c|}{$m m \dot{H g}$} & \multicolumn{4}{|c|}{$m m \mathrm{Hg}$} \\
\hline \multicolumn{8}{|c|}{ a. Intact animals } \\
\hline 150 & $161 / 72$ & $126 / 74$ & $140 / 84$ & 0.8 & & -0.1 & -0.5 \\
\hline 246 & $187 / 110$ & $135 / 64$ & $116 / 59$ & 2.3 & & 1.8 & 2.2 \\
\hline 228 & $182 / 117$ & $130 / 63$ & $107 / 50$ & 0.5 & & 0.3 & .0 .7 \\
\hline 246 & $180 / 120$ & $173 / 108$ & $180 / 95$ & -0.2 & & 1.4 & 1.0 \\
\hline 252 & $169 / 113$ & $145 / 108$ & $127 / 92$ & 2.4 & & 1.9 & 1.5 \\
\hline 168 & $152 / 101$ & $117 / 73$ & $129 / 85$ & -0.4 & & $-1,4$ & -1.5 \\
\hline 132 & $157 / 109$ & $134 / 100$ & $137 / 95$ & 3.2 & & 4.5 & 4 \\
\hline 96 & $148 / 99$ & $154 / 81$ & $157 / 99$ & -0.4 & & 1.8 & 0.9 \\
\hline $189.8 \pm 21.4$ & $167^{*} \pm 5.2$ & $139.3^{*} \pm 6.3$ & $136.6^{*} \pm 8.2$ & $1.03 \pm 0.47$ & & $1.3 \pm 0.62$ & $1.04 \pm 0.62$ \\
\hline$P_{\triangleleft}<0.01$ & & $P<0.01$ & $P<0.02$ & & & & \\
\hline \multicolumn{8}{|c|}{ b. Sotalol, beta adrenergic blockade animals (group III) } \\
\hline 99 & $\begin{array}{l}161 / 118 \\
137 / 100 \ddagger\end{array}$ & $117 / 85$ & $95 / 75$ & 6.0 & $6.0 \ddagger$ & 7.0 & 5.0 \\
\hline 102 & $\begin{array}{l}143 / 96 \\
110 / 80 \ddagger\end{array}$ & $85 / 55$ & $87 / 63$ & 3.6 & $2.7 \ddagger$ & 3.5 & 3.0 \\
\hline 138 & $\begin{array}{l}130 / 85 \\
125 / 90 \ddagger\end{array}$ & $113 / 82$ & $98 / 75$ & 2.5 & $3.2 \ddagger$ & 3.5 & 3.0 \\
\hline 126 & $\begin{array}{l}144 / 106 \\
137 / 106 \ddagger\end{array}$ & $112 / 83$ & $103 / 79$ & 1.9 & $2.0 \ddagger$ & 2.0 & 2.0 \\
\hline 111 & $\begin{array}{l}135 / 90 \\
118 / 88 \ddagger\end{array}$ & $104 / 75$ & $95 / 73$ & 2.0 & $2.0 \ddagger$ & 2.2 & 1.8 \\
\hline 96 & $\begin{array}{l}166 / 108 \\
168 / 113 \ddagger\end{array}$ & $119 / 80$ & $111 / 81$ & 3.2 & $2.0 \ddagger$ & 2.5 & 2.0 \\
\hline $112 \pm 6.8$ & $\begin{array}{l}146.5^{*} \pm 5.8 \\
132.5^{*} \ddagger \pm 7.8\end{array}$ & $108.3^{*} \pm 5.1$ & $98^{*} \pm 3.3$ & $3.2 \pm 0.67$ & $3.0 \ddagger \pm 0.64$ & $3.5 \pm 0.76$ & $2.8 \pm 0.49$ \\
\hline$P<0.02$ & $P<0.05$ & $P<0.01$ & $P<0.01$ & & & & \\
\hline
\end{tabular}

sults are plotted in Figs. 1 and 2 and are tabulated in Table III. Mean systolic blood pressure fell $10.5 \mathrm{~mm} \mathrm{Hg}$ immediately after phenoxybenzamine (from 73.3 to 62.8 $\mathrm{mm} \mathrm{Hg}$ ) but was $38.2 \mathrm{~mm} \mathrm{Hg}$ higher $10 \mathrm{~min}$ after phenoxybenzamine $(111.5 \mathrm{~mm} \mathrm{Hg})$. The control heart rates were more rapid in these animals than in groups I and II because we performed bilateral vagal section as part of the procedure for testing the completeness of ganglionic blockade. The heart rates were significantly decreased $5 \mathrm{~min}$ after ganglionic blockade (Table I). The heart rate did not increase significantly immediately after phenoxybenzamine or $5 \mathrm{~min}$ later but did show a significant rise after ten min.

The effects of phenoxybenzamine upon cardiac output after ganglionic blockade are shown in Fig. 2 and Table III. The cardiac output was significantly reduced after ganglionic blockade with no significant rise immediately after phenoxybenzamine or $5 \mathrm{~min}$ later. There was a significant increase of cardiac output over that immediately after ganglionic blockade $10 \mathrm{~min}$ after phenoxybenzamine.

Group $V$. (a) The percentage decrease from control in atrial rate induced by vagal stimulation carried 
TABLE II

Effects of Phenoxybenzamine upon Hemodynamics

\begin{tabular}{|c|c|c|c|c|c|c|c|}
\hline \multirow[b]{2}{*}{$\begin{array}{l}\text { Dog } \\
\text { No. }\end{array}$} & \multirow[b]{2}{*}{ Weight } & \multirow[b]{2}{*}{$\begin{array}{c}\text { NE, } 1 \mu \mathrm{gg} / \mathrm{kg} \\
\text { per cent } \\
\text { alpha } \\
\text { blockade }\end{array}$} & \multicolumn{3}{|c|}{ Cardiac output } & \multicolumn{2}{|c|}{ Heart rate } \\
\hline & & & Control & $\begin{array}{l}\text { Immed. } \\
\text { after } \\
\text { phenoxy- } \\
\text { benzamine }\end{array}$ & $\begin{array}{c}10 \mathrm{~min} \\
\text { after } \\
\text { phenoxy- } \\
\text { benzamine }\end{array}$ & Control & $\begin{array}{l}\text { Immed. } \\
\text { after } \\
\text { phenoxy- } \\
\text { benzamine }\end{array}$ \\
\hline \multirow{3}{*}{1492} & kg & & \multicolumn{3}{|c|}{$\mathrm{ml} / \mathrm{kg} / \min$} & \multicolumn{2}{|c|}{ beats/min } \\
\hline & 24.8 & & 70.6 & & & 84 & \\
\hline & & 87 & 78.9 & 156 & 129 & 66 & 210 \\
\hline \multirow[t]{2}{*}{1493} & 25.9 & & 109.2 & & & 147 & \\
\hline & & 97 & 116 & 169.5 & 156.1 & 138 & 186 \\
\hline \multirow[t]{2}{*}{1494} & 29.5 & & 129.8 & & & 90 & \\
\hline & & 38 & 110.2 & 121.5 & 154.8 & 111 & 96 \\
\hline \multirow[t]{2}{*}{1495} & 22.3 & & 129.8 & & & 78 & \\
\hline & & 79 & 125.2 & 370.8 & 313.2 & 78 & 264 \\
\hline \multirow[t]{2}{*}{1497} & 25 & & 184.8 & & & 99 & \\
\hline & & 99 & 178.4 & 354.7 & 248.3 & 108 & 240 \\
\hline \multirow[t]{2}{*}{1498} & 20.2 & & 144.7 & & & 81 & \\
\hline & & 73 & 159.1 & 274.8 & 392.6 & 84 & 180 \\
\hline \multicolumn{2}{|c|}{ Mean $\pm S E$} & & $127.2 \pm 14.8$ & $\begin{array}{c}241.2 \pm 37.9 \\
P<0.05\end{array}$ & $\begin{array}{c}232.3 \pm 37.1 \\
P<0.05\end{array}$ & $97 \pm 10.3$ & $\begin{array}{c}196 \pm 23.8 \\
P<0.02\end{array}$ \\
\hline
\end{tabular}

Dosage of phenoxybenzamine was $5 \mathrm{mg} / \mathrm{kg}$ body weight. The paired control measurements were averaged for statistical calculations. $P$ values are derived from the $t$ test, with changes compared to the control value.

* Systolic blood pressure mean of the six animals.

out before and after phenoxybenzamine is shown in $\mathrm{Ta}$ ble IV and in Fig. 5. The mean heart rate was significantly greater after phenoxybenzamine, 245.5, as compared to a control rate of 182.2 beats $/ \mathrm{min}, P<0.01$. The heart rate was a significantly higher percentage of the control after phenoxybenzamine at each frequency of stimulation, except at 30 cycles/second (Table IV and Fig. 5). In the three control animals that received only the vehicle, the heart rate was not significantly different in response to vagal stimulation when done before and after the vehicle. The vehicle consisted of $3 \mathrm{ml}$ of absolute alcohol and $47 \mathrm{ml}$ of physiologic saline. The absolute decreases of heart rate during vagal stimulation before and after phenoxybenzamine were compared ( $\mathrm{Ta}$ ble V). After phenoxybenzamine the absolute decrease was significantly less during vagal stimulation at 1 and 3 cycles/sec, but not at 10 cycles $/ \mathrm{sec}$. At a stimulation frequency of 30 cycles/sec the absolute decrease of heart rate was greater after phenoxybenzamine.

(b) Table VI shows the results of peripheral vagal nerve stimulation in group $\mathrm{V} b$. The heart rate response, expressed as a percentage of control, was not significantly decreased when the mean heart rate was increased from 178 to 235.8 per $\min$ by isoproterenol infusion (Table VI). In the same animals, the mean heart rate was 249.6 per min after phenoxybenzamine. The heart rate was sig- nificantly higher than during isoproterenol with vagal stimulation at 1 and $10 \mathrm{cycles} / \mathrm{sec}$, but not at $30 \mathrm{cycles} /$ sec. Animal No. 1625 had a heart rate after phenoxybenzamine comparable to that during isoproterenol infusion and demonstrated much less response to vagal stimulation after phenoxybenzamine (Table VI).

Group VI. Dog heart-lung preparations. In the two preparations in which $1 \mathrm{mg}$ of phenoxybenzamine per $\mathrm{kg}$ body weight was given, cardiac output, left atrial pressure, and left ventricular force did not change. In the four preparations in which phenoxybenzamine, $5 \mathrm{mg} / \mathrm{kg}$, was given, negative cardiac inotropic effects were pronounced in two and slight in two. In the two animals in which the effects were slight, cardiac outputs declined from 1111 to $909 \mathrm{ml} / \mathrm{min}$ and from 1250 to $1071 \mathrm{ml} / \mathrm{min}$, respectively. In the two animals with pronounced negative inotropic effects the cardiac outputs decreased from 909 to $294 \mathrm{ml} / \mathrm{min}$ (Fig. 6) and from 1035 to $161 \mathrm{ml} / \mathrm{min}$ after phenoxybenzamine. In each of these four animals the left ventricular force decreased, and the left atrial pressure increased after phenoxybenzamine (Fig. 6). Administration of the vehicle had no effects upon these variables. The phenoxybenzamine had no significant effect upon heart rate in these heartlung preparations. 
in Open-Chest Dogs (Group 1b)

\begin{tabular}{|c|c|c|c|c|c|c|}
\hline \multirow{2}{*}{ 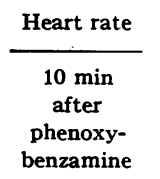 } & \multicolumn{3}{|c|}{ Arterial blood pressure } & \multicolumn{3}{|c|}{ Left atrial mean pressure } \\
\hline & Control & $\begin{array}{l}\text { Immed. } \\
\text { after } \\
\text { phenoxy- } \\
\text { benzamine }\end{array}$ & $\begin{array}{c}10 \mathrm{~min} \\
\text { after } \\
\text { phenoxy- } \\
\text { benzamine }\end{array}$ & Control & $\begin{array}{c}\text { Immed. } \\
\text { after } \\
\text { phenoxy- } \\
\text { benzamine }\end{array}$ & $\begin{array}{c}10 \mathrm{~min} \\
\text { after } \\
\text { phenoxy- } \\
\text { benzamine }\end{array}$ \\
\hline \multirow[t]{2}{*}{ beats/min } & & $m m \mathrm{Hg}$ & & & $m m \mathrm{Hg}$ & \\
\hline & $134 / 75$ & & & 2.7 & & \\
\hline \multirow[t]{2}{*}{216} & $138 / 75$ & $95 / 70$ & $83 / 53$ & 2.8 & 1.7 & 1.0 \\
\hline & $158 / 116$ & - & & 3.4 & & \\
\hline \multirow[t]{2}{*}{198} & $162 / 116$ & $123 / 71$ & $105 / 57$ & 4.2 & 3.0 & 3.1 \\
\hline & $154 / 95$ & & & 7.5 & & \\
\hline \multirow[t]{2}{*}{144} & $157 / 98$ & $137 / 77$ & $121 / 77$ & 7.5 & 6.3 & 5.8 \\
\hline & $\begin{array}{l}170 / 113 \\
180 / 85\end{array}$ & $137 / 81$ & $127 / 76$ & $\begin{array}{l}2.8 \\
3.0\end{array}$ & 5.9 & 4.0 \\
\hline 270 & $\begin{array}{l}181 / 120 \\
182 / 122\end{array}$ & $123 / 67$ & $116 / 71$ & $\begin{array}{l}0.8 \\
0.8\end{array}$ & 2.6 & 1.7 \\
\hline 210 & $\begin{array}{l}146 / 87 \\
147 / 75\end{array}$ & $130 / 73$ & $163 / 67$ & $\begin{array}{r}8.8 \\
10.5\end{array}$ & 8.0 & 8.5 \\
\hline $\begin{array}{c}213 \pm 17.1 \\
P<0.01\end{array}$ & $159 \pm 6.9^{*}$ & $\begin{array}{c}124 \pm 6.3^{*} \\
P<0.01\end{array}$ & $\begin{array}{c}119 \pm 10.8^{*} \\
P=0.02\end{array}$ & $4.6 \pm 1.3$ & $4.6 \pm 1.0$ & $4.0 \pm 1.1$ \\
\hline
\end{tabular}

Group VII. The hemodynamic effects of phenoxybenzamine $10 \mathrm{mg} / \mathrm{kg}$ given intravenously in dogs with baroreceptor denervation are summarized in Table VII. The hemodynamic changes produced by phenoxybenzamine in group I a intact dogs are also shown for comparison. In the five group VII animals, control cardiac outputs, systolic blood pressure, and heart rates were comparable to those in group I intact animals. After baroreceptor denervation, heart rate and systolic blood pressure rose; there was a significant increase in cardiac output. Immediately after phenoxybenzamine, the mean cardiac output did not rise in the group VII baroreceptor denervated animals (Table VII). The cardiac output rose an average of $51 \%$ in the intact animals; the difference was significant statistically, $P<0.02$. $10 \mathrm{~min}$ after phenoxybenzamine, the mean cardiac output increased $55.5 \%$ over control in the intact animals, but was $23.1 \%$ less than control in the baroreceptor-denervated animals. The difference was significant statistically, $P<0.02$. Phenoxybenzamine administration was followed by a much greater increase in heart rate in the intact animals and by a much lower arterial blood pressure in the baroreceptor-denervated animals.

\section{DISCUSSION}

Our studies showed a consistent increase of cardiac output and of heart rate in anesthetized intact dogs after phenoxybenzamine, $10 \mathrm{mg} / \mathrm{kg}$ body weight given intravenously. We considered several possible mechanisms of this action. These included a direct cardiac effect of phenoxybenzamine, liberation of catecholamines from the adrenal medulla and sympathetic nerve endings, an antivagal action, direct stimulation of the sympathetic nervous system, and a reflex effect operating through the carotid and aortic baroreceptors which were affected by the fall in blood pressure resulting from alpha adrenergic receptor blockade.

We investigated the possibility of a direct cardiac effect of phenoxybenzamine in dog heart-lung preparations. Small doses of phenoxybenzamine $(1 \mathrm{mg} / \mathrm{kg})$ had no effect or a negative inotropic effect; larger doses (5 $\mathrm{mg} / \mathrm{kg}$ ) had only a negative inotropic effect with no consistent chronotropic action. Hence, we concluded that the observed positive inotropic and chronotropic effects of phenoxybenzamine in intact dogs were not related to direct cardiac effects or release of myocardial norepinephrine stores. These results are analogous to those reported by Moran and Perkins (11) and by Cotten, Moran, and Stopp (12). These investigators 


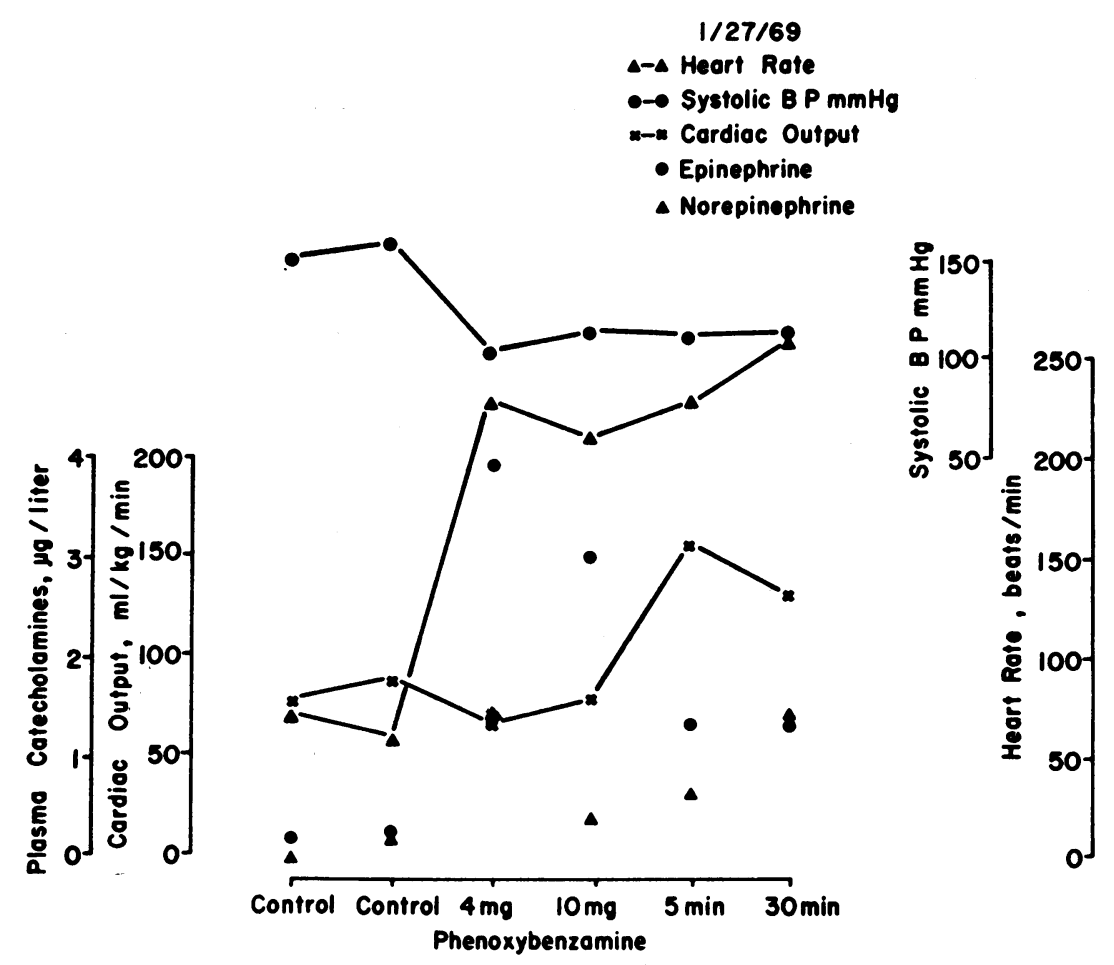

FIGURE 3 Graph showing lack of relation between change in cardiac output and absolute levels of arterial epinephrine and norepinephrine after phenoxybenzamine, $10 \mathrm{mg} / \mathrm{kg}$, intravenously.

found that phenoxybenzamine $20 \mathrm{mg} / \mathrm{kg}$ intravenously increased the heart rate and right ventricular contractile force in dogs. In the perfused rabbit heart, phenoxybenzamine 5 or $10 \mu \mathrm{g} / \mathrm{ml}$ depressed cardiac contractility and the response to epinephrine. These observations differ from those reported by Chang (13) who found that $0.1-0.2 \mu \mathrm{g}$ of phenoxybenzamine had positive inotropic and chronotropic effects in the isolated perfused rat heart. These actions were prevented by reserpine pretreatment or by propranolol or MJ-1999. It was suggested that phenoxybenzamine exerted sympathomimetic effects by releasing catecholamines from the heart as shown previously (14). The difference between Chang's observations and ours may be related to the small drug concentrations employed by him, or to a species difference. Chang did find negative inotropic effects of phenoxybenzamine in his studies when the dose was increased to $0.5 \mu \mathrm{g}$.

We examined the possibility that circulating epinephrine and norepinephrine released from sympathetic nerve endings and the adrenal medulla might be responsible for the increased heart rate and cardiac output after phenoxybenzamine. Benfey, Ledoux, and Melville found that phenoxybenzamine, 10 and $20 \mathrm{mg} / \mathrm{kg}$, increased the

TABLE III

Effects of Ganglionic Blockade upon Hemodynamic Response to Phenoxybenzamine

\begin{tabular}{|c|c|c|c|c|c|c|c|}
\hline & \multirow{2}{*}{$\begin{array}{c}\text { Control } \\
1\end{array}$} & \multirow{2}{*}{$\begin{array}{l}\text { Control } \\
2\end{array}$} & \multirow{2}{*}{$\begin{array}{l}5 \text { min after } \\
\text { ganglionic } \\
\text { blockade }\end{array}$} & \multirow{2}{*}{$\begin{array}{l}10 \text { min after } \\
\text { ganglionic } \\
\text { blockade }\end{array}$} & \multicolumn{3}{|c|}{ After phenoxybenzamine } \\
\hline & & & & & Immediate & $5 \mathrm{~min}$ & $10 \mathrm{~min}$ \\
\hline $\begin{array}{l}\text { Heart rate, } \\
\text { beats } / \text { min } \\
\text { (Mean } \pm \mathrm{SE})\end{array}$ & $195 \pm 6.3$ & $193.1 \pm 6.1$ & $\begin{array}{c}139.5 \pm 11.1 \\
P<0.01\end{array}$ & $\begin{array}{c}145.3 \pm 11.8 \\
P<0.01\end{array}$ & $\begin{array}{c}150 \pm 15.6 \\
P>0.9\end{array}$ & $\begin{array}{c}156 \pm 11.2 \\
P>0.1\end{array}$ & $\begin{array}{c}164.5 \pm 10.1 \\
P<0.02\end{array}$ \\
\hline $\begin{array}{c}\text { Cardiac output, } \\
\mathrm{ml} / \mathrm{kg} / \mathrm{min} \\
\text { (Mean } \pm \mathrm{SE})\end{array}$ & $110 \pm 10.2$ & $115 \ldots \pm 10.5$ & $\begin{array}{l}76 \pm 9.0 \\
P<0.01\end{array}$ & $\begin{array}{c}81 \pm 10.5 \\
P<0.01\end{array}$ & $\begin{array}{l}81 \pm 13.5 \\
P>0.9\end{array}$ & $\begin{array}{l}96 \pm 7.1 \\
P>0.1\end{array}$ & $\begin{array}{c}108 \pm 10.8 \\
P<0.02\end{array}$ \\
\hline
\end{tabular}




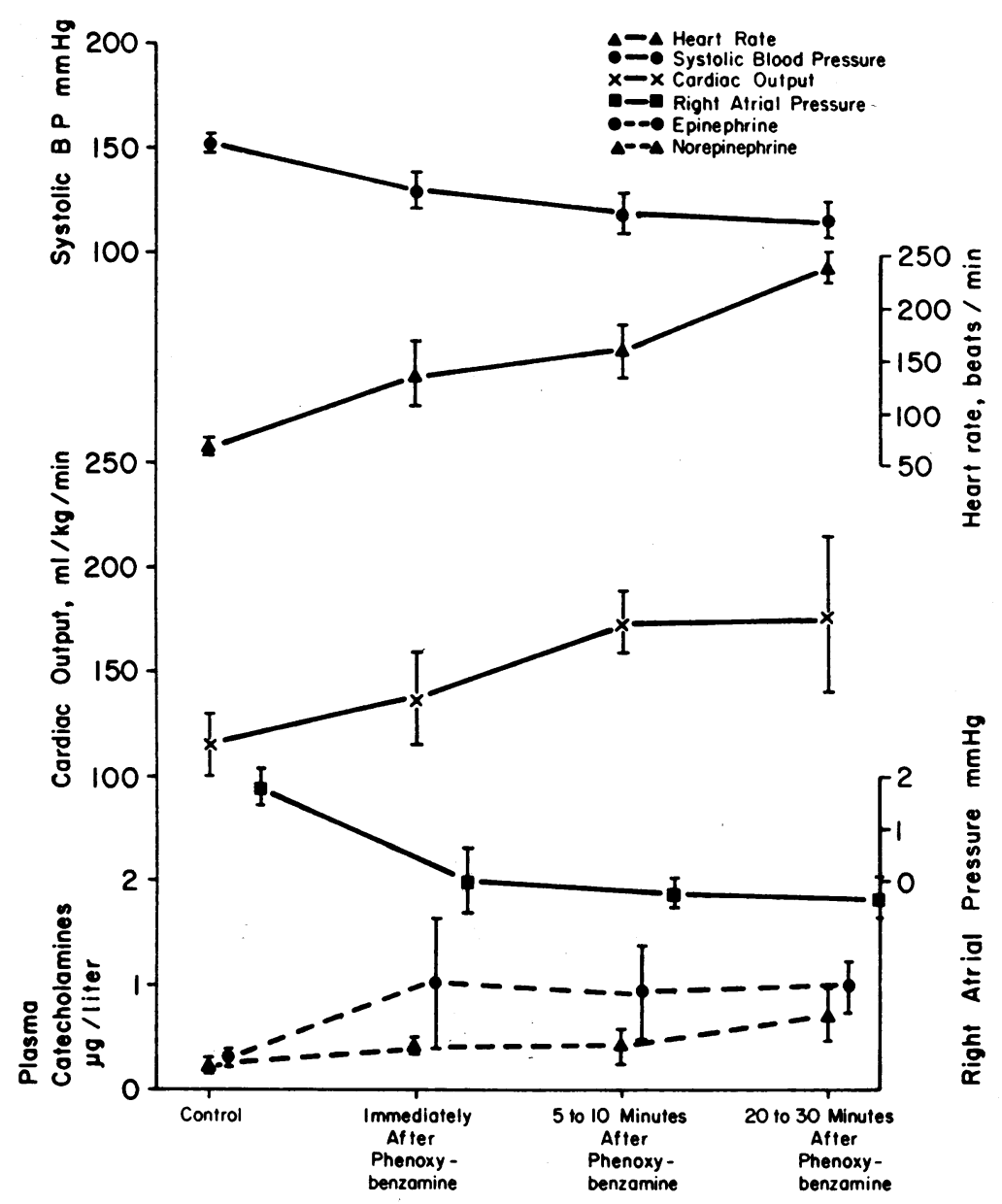

FIGURE 4 Graph of relation between blood epinephrine and norepinephrine after phenoxybenzamine, $10 \mathrm{mg} / \mathrm{kg}$ intravenously, and cardiac output, heart rate, and systolic blood pressure in the four animals of group II.

urinary output of adrenaline and noradrenaline in dogs anesthetized with phenobarbitone (15). Willey (16) found in cats that phenoxybenzamine, $10 \mathrm{mg} / \mathrm{kg}$, increased the vasopressor activity of splenic venous and femoral arterial plasma. Arterial blood epinephrine and norepinephrine rise after phenoxybenzamine (17). Phenoxybenzamine interferes with the destruction of noradrenaline in the body (18). Evidence of increased

TABLE IV

Antivagal Effects of Phenoxybenzamine: Percentage Changes in Heart Rate during Vagal Stimulation

\begin{tabular}{|c|c|c|c|c|c|c|c|c|c|c|}
\hline \multirow{2}{*}{$\begin{array}{l}\text { Dog } \\
\text { No. }\end{array}$} & \multirow{2}{*}{$\begin{array}{c}\text { Initial } \\
\text { heart rate }\end{array}$} & \multicolumn{4}{|c|}{$\begin{array}{c}\text { Control } \\
\text { Percentage initial heart rate during } \\
\text { vagal stimulation }\end{array}$} & \multirow{2}{*}{$\begin{array}{c}\text { Initial } \\
\text { heart rate }\end{array}$} & \multicolumn{4}{|c|}{$\begin{array}{l}\text { Phenoxybenzamine } \\
\text { Percentage initial heart rate during } \\
\text { vagal stimulation }\end{array}$} \\
\hline & & $1 / \mathrm{sec}$ & $3 / \mathrm{sec}$ & $10 / \sec$ & $30 / \sec$ & & $1 / \mathrm{sec}$ & $3 / \mathrm{sec}$ & $10 / \mathrm{sec}$ & $30 / \mathrm{sec}$ \\
\hline 1582 & 180 & 78 & 60 & 22 & 0 & 246 & 94 & 80 & 58 & 26 \\
\hline 1584 & 180 & 69 & 46 & 9 & 0 & 219 & 90 & 82 & 34 & 0 \\
\hline 1592 & 197 & 73 & 70 & 37 & 0 & 240 & 100 & 80 & 58 & 0 \\
\hline 1594 & 194 & 65 & 46 & 19 & 6 & 246 & 98 & 78 & 51 & 32 \\
\hline 1604 & 168 & 53 & 45 & 24 & 11 & 282 & 88 & 78 & 52 & 21 \\
\hline 1606 & 174 & 78 & 59 & 28 & 0 & 240 & 94 & 73 & 38 & 0 \\
\hline \multirow[t]{2}{*}{ Mean \pm SE } & $182.2 \pm 4.6$ & $69.3 \pm 3.9$ & $54.3 \pm 4.2$ & $23.2 \pm 3.8$ & $17 \pm 1.9$ & $245.5 \pm 8.4$ & $94 \pm 1.9$ & $78.5 \pm 1.3$ & $48.5 \pm 4.2$ & $13.2 \pm 6.1$ \\
\hline & & & & I & & $P<0.01$ & $P<0.001$ & $P<0.01$ & $P<0.01$ & $P>0.2$ \\
\hline
\end{tabular}




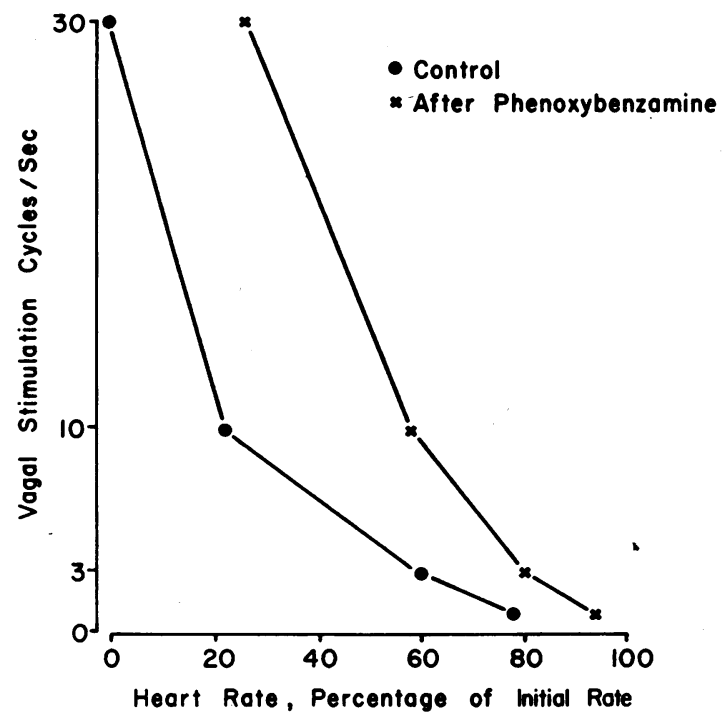

FIGURE 5 Effect of phenoxybenzamine, $10 \mathrm{mg} / \mathrm{kg}$ intravenously, upon vagal frequency/response curve in one animal showing antivagal effect.

adrenal and splenic catecholamine release during nerve stimulation has been found after phenoxybenzamine (19). Our studies confirm the increase of arterial plasma epinephrine and norepinephrine after intravenous phenoxybenzamine. The peak increase of the plasma levels of these catecholamines did not correlate with the maximum observed changes in cardiac output and heart rate. Thus it is not certain whether or not circulating catecholamines were principally responsible for the cardiac rate and output changes which were observed after phenoxybenzamine.

Sotalol (dl MJ-1999) is an effective beta sympathetic receptor blocking agent. Levy and Richards (20) used $9.4 \times 10^{-8} \mathrm{M}$ isoproterenol and the isolated beating rabbit atrium to study the beta adrenergic blocking effects of sotalol. The concentration required to achieve $50 \%$ inhibition of the positive inotropic effects of isopro- terenol indicated that sotalol had somewhat less than one-tenth the action of $d l$-propranolol. However, propranolol depressed myocardial contractility; this effect was absent in equal or higher concentration of sotalol. Hence sotalol seemed a better choice than propranolol as a beta blocking agent in experiments. Sotalol has been found to block the effect of tyramine on isolated rabbit atria and thus is believed to prevent norepinephrine release $(21)$. In the present experiments, sotalol effectively prevented an increase in cardiac output after phenoxybenzamine. The heart rate increased only in the $10 \mathrm{~min}$ period after phenoxybenzamine and then did not exceed control values significantly. The effective blockade of the effects of phenoxybenzamine upon heart rate and cardiac output by sotalol is consistent with an action mediated by the sympathetic cardiac nerves or by circulating catecholamines. Such sympathetic stimulation might be effected either through reflex action or by direct stimulation of sympathetic nerve centers, ganglia, or peripheral nerves. The decrease in afterload produced by phenoxybenzamine might be expected to increase cardiac output even in the absence of effective cardiac sympathetic innervation. However this anticipated increase of cardiac output might not occur if venous return were decreased or if the heart were depressed by impaired coronary flow or by sotalol or phenoxybenzamine. Venomotion depends upon both alpha and beta adrenergic receptors (22). Thus the administration of both phenoxybenzamine, an alpha adrenergic blocking agent, and sotalol, a beta adrenergic blocking agent, might be expected to impair venous return to the heart, thus limiting the cardiac output response. Phenoxybenzamine alone, since it affects only alpha adrenergic receptors, woud not be expected to impair cardiac venous return to the same degree. Right atrial pressures were essentially unchanged after phenoxybenzamine in both our control animals and in those with beta adrenergic blockade. Hence we had no clear evidence of either cardiac depression or impaired venous return.

TABLE V

Antivagal Effects of Phenoxybenzamine: Numerical Changes in Heart Rate during Vagal Stimulation

\begin{tabular}{|c|c|c|c|c|c|c|c|c|c|c|}
\hline \multirow{2}{*}{$\begin{array}{l}\text { Dog } \\
\text { No. }\end{array}$} & \multirow{2}{*}{$\begin{array}{c}\text { Initial } \\
\text { heart rate }\end{array}$} & \multicolumn{4}{|c|}{$\begin{array}{c}\text { Control } \\
\text { Decrease from initial rate during } \\
\text { vagal stimulation }\end{array}$} & \multirow{2}{*}{$\begin{array}{c}\text { Initial } \\
\text { heart rate }\end{array}$} & \multicolumn{4}{|c|}{$\begin{array}{l}\text { Phenoxybenzamine } \\
\text { Decrease from initial rate during } \\
\text { vagal stimulation }\end{array}$} \\
\hline & & $1 / \sec$ & $3 / \mathrm{sec}$ & $10 / \mathrm{sec}$ & $30 / \mathrm{sec}$ & & $1 / \mathrm{sec}$ & $3 / \mathrm{sec}$ & $10 / \mathrm{sec}$ & $30 / \mathrm{sec}$ \\
\hline 1582 & 180 & 40 & 72 & 140 & 180 & 246 & 14 & 50 & 106 & 182 \\
\hline 1584 & 180 & 56 & 96 & 164 & 180 & 219 & 21 & 39 & 141 & 219 \\
\hline 1592 & 197 & 53 & 59 & 127 & 197 & 240 & 0 & 48 & 102 & 240 \\
\hline 1594 & 194 & 68 & 104 & 158 & 182 & 246 & 6 & 54 & 138 & 168 \\
\hline 1604 & 168 & 69 & 84 & 12.3 & 147 & 282 & 33 & 63 & 135 & 222 \\
\hline 1606 & 174 & 39 & 72 & 126 & 174 & 240 & 15 & 66 & 150 & 240 \\
\hline Mean $\pm \mathrm{SE}$ & $182.2 \pm 4.6$ & $54.2 \pm 5.3$ & $81.2 \pm 6.85$ & $139.7 \pm 7.2$ & $176.7 \pm 6.7$ & $\begin{array}{c}245.5 \pm 8.4 \\
P<0.01\end{array}$ & $\begin{array}{l}14.8 \pm 4.7 \\
P<0.01\end{array}$ & $\begin{array}{c}53.3 \pm 4.1 \\
P<0.05\end{array}$ & $\begin{array}{c}128.7 \pm 8.1 \\
P>0.3\end{array}$ & $211.8 \pm 12.3$ \\
\hline
\end{tabular}



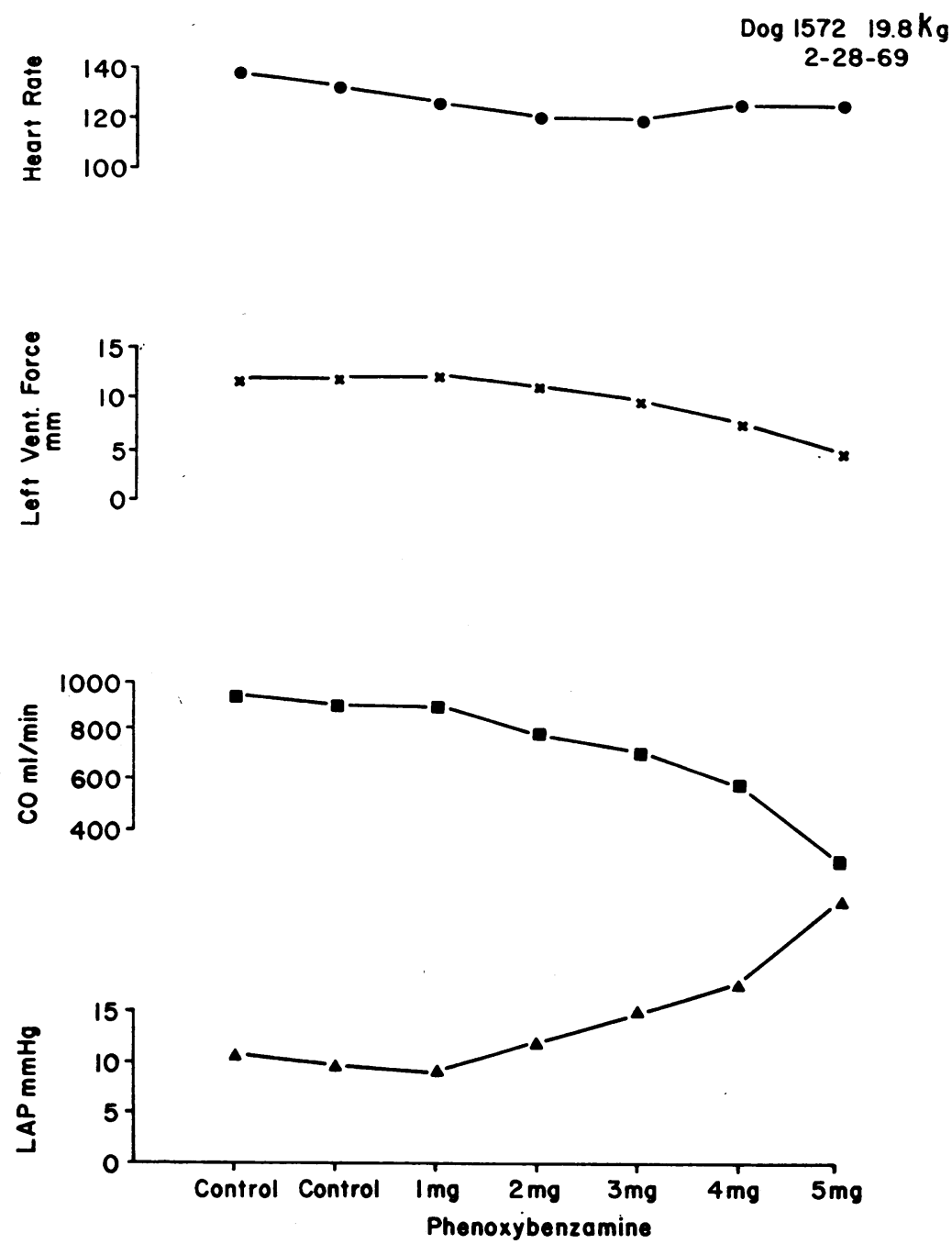

FIGURE 6 Graph showing negative cardiac inotropic effect of phenoxybenzamine in dog heart-lung preparation. The doses of phenoxybenzamine are given at 2-min intervals and are expressed in milligrams per kilogram body weight.

TABLE VI

Effects of Isoproterenol and of Phenoxybenzamine upon Heart Rate Response to Vagal Stimulation (Group Vb)

\begin{tabular}{|c|c|c|c|c|c|c|c|c|c|c|c|c|}
\hline \multirow{2}{*}{$\begin{array}{l}\text { Dog } \\
\text { No. }\end{array}$} & \multirow{2}{*}{$\begin{array}{l}\text { Control } \\
\text { heart } \\
\text { rate } \\
\text { per } \\
\text { min }\end{array}$} & \multicolumn{3}{|c|}{$\begin{array}{l}\text { Control } \\
\text { Heart rate, per cent of } \\
\text { initial rate; during vagal } \\
\text { stimulation }\end{array}$} & \multirow{2}{*}{$\begin{array}{l}\text { Control } \\
\text { heart } \\
\text { rate } \\
\text { per } \\
\text { min }\end{array}$} & \multicolumn{3}{|c|}{$\begin{array}{l}\text { Isoproterenol infusion } \\
\text { Heart rate, per cent of } \\
\text { initial rate; during vagal } \\
\text { stimulation }\end{array}$} & \multirow{2}{*}{$\begin{array}{l}\text { Control } \\
\text { heart } \\
\text { rate } \\
\text { per } \\
\text { min }\end{array}$} & \multicolumn{3}{|c|}{$\begin{array}{l}\text { Phenoxybenzamine, } 10 \mathrm{mg} / \mathrm{kg} \\
\text { Heart rate, per cent of initial rate; } \\
\text { during vagal stimulation }\end{array}$} \\
\hline & & $\begin{array}{l}1 / \\
\text { sec }\end{array}$ & $\begin{array}{l}10 / \\
\mathrm{sec}\end{array}$ & $\begin{array}{l}30 / \\
\mathrm{sec}\end{array}$ & & $\begin{array}{l}1 / \\
\mathrm{sec}\end{array}$ & $\begin{array}{l}10 / \\
\text { sec }\end{array}$ & $\begin{array}{l}30 / \\
\text { sec }\end{array}$ & & $1 / \mathrm{sec}$ & $10 / \mathrm{sec}$ & $30 / \mathrm{sec}$ \\
\hline 1623 & 182 & 61 & 31 & 26 & 231 & 55 & 22 & 19 & 264 & 95 & 65 & 45 \\
\hline 1625 & 198 & 73 & 18 & 12 & 252 & 93 & 57 & 36 & 258 & 98 & 93 & 91 \\
\hline 1627 & 192 & 83 & 33 & 0 & 240 & 72 & 34 & 0 & 270 & 100 & 92 & 51 \\
\hline 1632 & 168 & 75 & 29 & 29 & 234 & 58 & 17 & 20 & 258 & 92 & 63 & 5 \\
\hline 1638 & 150 & 80 & 36 & 12 & 222 & 70 & 35 & 0 & 198 & 85 & 42 & 0 \\
\hline Mean & 178 & 74.4 & 29.4 & 15.8 & 235.8 & 69.6 & 33 & 15 & 249.6 & $\stackrel{94}{P<0.05}$ & $\begin{array}{l}71 \\
P<0.01\end{array}$ & $\begin{array}{l}38.4 \\
P>0.2\end{array}$ \\
\hline
\end{tabular}


TABLE VII

Hemodynamic Effects of Phenoxybenzamine

\begin{tabular}{|c|c|c|c|c|c|c|}
\hline & \multicolumn{3}{|c|}{ Control } & \multicolumn{3}{|c|}{ Denervation } \\
\hline & $\begin{array}{l}\text { Heart } \\
\text { rate }\end{array}$ & $\begin{array}{l}\text { Systolic } \\
\text { BP }\end{array}$ & $\begin{array}{l}\text { Cardiac } \\
\text { output* }\end{array}$ & $\begin{array}{l}\text { Heart } \\
\text { rate }\end{array}$ & $\begin{array}{c}\text { Systolic } \\
\text { BP }\end{array}$ & $\begin{array}{l}\text { Cardiac } \\
\text { output }\end{array}$ \\
\hline & & $m m \mathrm{Hg}$ & & & $m m \mathrm{Hg}$ & \\
\hline $\begin{array}{l}\text { Group Ia } \\
\text { Intact } \\
\text { animals }\end{array}$ & $87.8 \pm 11.2$ & 167 & $131.7 \pm 12.4$ & - & - & - \\
\hline $\begin{array}{l}\text { Group VII } \\
\text { Baroreceptor } \\
\text { denervation }\end{array}$ & $82.2 \pm 7.9$ & 160 & $124.8 \pm 9.9$ & $224 \pm 8.1$ & 193.8 & $\begin{array}{l}177 \pm 21.2 \\
P<0.05 \ddagger\end{array}$ \\
\hline
\end{tabular}

Data are expressed as mean values \pm SE. Figures in.parentheses are percentage changes from control.

* Cardiac output in milliliters per.kilogram per minute.

$\ddagger$ Change from control cardiac output.

In order to determine whether or not phenoxybenzamine might act upon autonomic ganglia or postganglionic sympathetic nerves, ganglionic blockade was induced by hexamethonium before phenoxybenzamine was administered. Atropine was also given since autonomic ganglia contain cholinoceptive sites, some of which are stimulated by nicotine and some of which are muscarinic receptors $(10,23)$. The cardiac output and heart rate increase after phenoxybenzamine was delayed until the 10 min period and was significantly less than without ganglionic blockade. Neither heart rate nor cardiac output exceeded the values preceding ganglionic blockade, which of itself tended to decrease heart rate and cardiac output. The minor cardiac effects of phenoxybenzamine after ganglionic blockade might result from circulating catecholamines, stimulation of postganglionic sympathetic nerve endings, or antivagal effects. In our studies, however, antivagal effects should have been already maximal because of the administration of atropine, 1 $\mathrm{mg} / \mathrm{kg}$ before phenoxybenzamine. The immediate fall and later rise in blood pressure after phenoxybenzamine in animals undergoing ganglionic blockade was also observed by Benfey (24). He was uncertain of the mechanism but speculated that the effect might result from catecholamine release, since atropine and ganglionic blocking drugs potentiate the hypertensive effects of norepinephrine.

Peripheral vagal stimulation frequency response curves showed evidence of antivagal action after phenoxybenzamine in each of our animals studied. Tachycardia induced by isoproterenol infusion did not impair the cardiac slowing induced by vagal stimulation. Hence the diminished response of the heart rate to vagal stimulation after phenoxybenzamine should not have been a nonspecific effect of tachycardia. Benfey (25) found no effect of phenoxybenzamine, $10 \mathrm{mg} / \mathrm{kg}$, upon the negative chronotropic action of vagal stimulation or methacholine injection. His experiments differed from ours in that pentobarbitone anesthesia was used and his animals might have had lower vagal tone initially (26). A more recent study has described a vagal blocking action of phenoxybenzamine as determined by direct perfusion of the sinoatrial node (27).

Our studies show clearly that beta adrenergic receptor blockade prevented increased cardiac rate and cardiac output after phenoxybenzamine. This observation appears to indicate that the antivagal effects of phenoxybenzamine do not play a major part in the tachycardia observed after its administration. There is some question as to whether or not an antivagal effect can increase the heart rate in the absence of beta adrenergic cardiac nerve function. Vagal section was found to cause little cardiac acceleration in dogs when cardiac sympathectomy had been performed after vagotomy (28). For this reason, we studied four dogs with beta receptor blockade produced by sotalol, $5 \mathrm{mg} / \mathrm{kg}$ intravenously. Bilateral cervical vagotomy increased the heart rates from 93 to 133 and from 50 to 102 beats $/ \mathrm{min}$, respectively, in two dogs. In the other two, after atropine, $0.2 \mathrm{mg} / \mathrm{kg}$ intravenously, the heart rates rose from 108 to 135 and from 63 to 198 beats/min, respectively. Thus, if phenoxybenzamine's antivagal action had a major responsibility for increasing the heart rate, it should have been demonstrable after beta adrenergic receptor blockade in our experiments.

Baroreceptor denervation effectively prevented an increase of cardiac output after phenoxybenzamine thus supporting the concept that the increase of heart rate and cardiac output are reflexly mediated by effects upon the carotid and aortic baroreceptors. Even though 
in Baroreceptor-Denervated Dogs

\begin{tabular}{|c|c|c|c|c|c|}
\hline \multicolumn{3}{|c|}{ Immediately after phenoxybenzamine $10 \mathrm{mg} / \mathrm{kg}$} & \multicolumn{3}{|c|}{10 min after phenoxybenzamine } \\
\hline $\begin{array}{l}\text { Heart } \\
\text { rate }\end{array}$ & $\begin{array}{l}\text { Systolic } \\
\text { BP }\end{array}$ & $\begin{array}{l}\text { Cardiac } \\
\text { output }\end{array}$ & $\begin{array}{l}\text { Heart } \\
\text { rate }\end{array}$ & $\begin{array}{l}\text { Systolic } \\
\text { BP }\end{array}$ & $\begin{array}{l}\text { Cardiac } \\
\text { output }\end{array}$ \\
\hline \multicolumn{3}{|c|}{$m m \mathrm{Hg}$} & \multicolumn{3}{|c|}{$m m \mathrm{Hg}$} \\
\hline $196.5 \pm 18.9$ & 139.3 & $\begin{array}{c}193.4 \pm 13.8 \\
(+51 \% \pm 12.1) \\
P<0.02\end{array}$ & $189.8 \pm 21.4$ & 136.6 & $\begin{array}{c}197.8 \pm 24 \\
(+55.7 \% \pm 18.3) \\
P<0.02\end{array}$ \\
\hline $244.8 \pm 3.9$ & 96.0 & $\begin{array}{c}170 \pm 8.5 \\
(-10.3 \% \pm 9.1)\end{array}$ & $243.6 \pm 3.1$ & 71.0 & $\begin{array}{c}129.6 \pm 8.8 \\
(-23.1 \% \pm 9.7)\end{array}$ \\
\hline
\end{tabular}

baroreceptors may exist in the common carotid arteries of cats (29), they did not seem effective in mediating an increase of cardiac output in our animals. We could not evaluate the role of the baroreceptors in increasing the heart rate after phenoxybenzamine, since the vagal section necessary for aortic arch denervation produced a nearly maximum heart rate before phenoxybenzamine was given. Since the changes in cardiac output did not correlate temporally with changes in blood catecholamine levels, it is possible that the baroreceptor effects of phenoxybenzamine are mediated neurogenically rather than humorally. It is concluded that phenoxybenzamine increases the heart rate and cardiac output principally by decreasing the systemic blood pressure, thus decreasing stimulation of receptors in the carotid sinus and aortic arch, which in turn act upon the heart through sympathetic nerves or circulating catecholamines.

\section{ACKNOWLEDGMENTS}

This study was supported in part by U. S. Public Health Service Grants HE-06307 and HE-05445.

\section{REFERENCES}

1. Bloch, J. H., C. H. Pierce, and R. C. Lillehei. 1965. Augmentation of myocardial function with phenoxybenzamine in dogs with cardiogenic shock. Fed. Proc. 24: 529.

2. Murphy, G. P., J. A. Gagnon, and R. A. Ewald. 1965. Renal and systemic hemodynamic effects of dibenzyline in normotension and hemorrhagic hypotension. Surgery. $57: 856$.

3. Fowler, N. O., and J. C. Holmes. 1969. Hemodynamic effects of isoproterenol and norepinephrine in acute cardiac tamponade. J. Clin. Invest. 48: 502.

4. Aviado, D. M. 1965. Pharmacologic approach to the treatment of shock. Ann. Intern. Med. 62: 1050.
5. Nickerson, M. 1949. The pharmacology of adrenergic blockade. Pharmacol. Rev. 1: 27.

6. Nickerson, M. 1965. Drugs inhibiting adrenergic nerves and structures innervated by them. In The Phamacological Basis of Therapeutics. L. S. Goodman and A. Gilman, editors. The Macmillan Company, New York. Third edition. 546.

7. Mills, L. C., and J. H. Moyer, editors. 1965. Shock and Hypotension: Pathogenesis and Treatment. Grune and Stratton, Inc., New York.

8. Bertler, A., A. Carlsson, and E. Rosengren. 1958. A method for the fluorimetric determination of adrenaline and noradrenaline in tissues. Acta Physiol. Scand. 44: 273.

9. Crout, J. R., C. R. Creveling, and S. Undenfriend. 1961. Norepinephrine metabolism in rat brain and heart. J. Pharmacol. Exp. Ther. 132: 269.

10. Trendelenburg, U. 1966. Transmission of preganglionic impulses through the muscarinic receptors of the superior cervical ganglion of the cat. J. Pharmacol. Exp. Ther. 154: 426.

11. Moran, N. C., and M. E. Perkins. 1961. An evaluation of adrenergic blockade of the mammalian heart. J. Pharmacol. Exp. Ther. 133: 192.

12. Cotten, M. de V., N. C. Moran, and P. E. Stopp. 1957. A comparison of the effectiveness of adrenergic blocking drugs in inhibiting the cardiac actions of sympathomimetic amines. J. Pharmacol. Exp. Ther. 121: 183.

13. Chang, P. 1968. Sympathomimetic actions of phenoxybenzamine on rat heart. Eur. J. Pharmacol. 4: 240.

14. Schapiro, S. 1958. Effect of a catechol amine blocking agent (dibenzyline) on organ content and urine excretion of noradrenaline and adrenaline. Acta Physiol. Scand. 42: 371.

15. Benfey, B. G., G. Ledoux, and K. I. Melville. 1959. Increased urinary excretion of adrenaline and noradrenaline after phenoxybenzamine. Brit. J. Pharmacol. 14: 142.

16. Willey, G. L. 1962. Effect of antisympathomimetic drugs on the plasma concentrations of catechol amines. Brit. J. Pharmacol. 19: 365.

17. Millar, R. A., E. B. Keener, and B. G. Benfey. 1959. Plasma adrenaline and noradrenaline after phenoxy-

Hemodynamic Effects of Phenoxybenzamine 
benzamine administration, and during haemorrhagic hypotension, in normal and adrenalectomized dogs. Brit. J. Pharmacol. 14: 9.

18. Benfey, B. G., G. Ledoux, and M. Segal. 1959. The action of antisympathomimetic drugs on the urinary excretion of adrenaline and noradrenaline. Brit. J. Pharmacol. $14: 380$.

19. Kirpekar, S. M., and P. Cervoni. 1963. Effect of cocaine, phenoxybenzamine and phentolamine on the catecholamine output from spleen and adrenal medulla. J. Pharmacol. Exp. Ther. 142: 59.

20. Levy, J. V., and V. Richards. 1966. Inotropic and chronotropic effects of a series of B-adrenergic blocking drugs: some structure-activity relationships. Proc. Soc. Exp. Biol. Med. 122: 373.

21. Aramendia, P., and A. J. Kaumann. 1967. Inhibition of sympathomimetic effects on the cardiovascular system by 4-(2-isopropylamino-1-hydroxyethyl) methanesulfonanilide hydrochloride (MJ 1999). J. Pharmacol. Exp. Ther. 155: 259.

22. Kaiser, G. A., J. Ross, Jr., and E. Braunwald. 1964. Alpha and beta adrenergic receptor mechanisms in the systemic venous bed. J. Pharmacol. Exp. Ther. 144: 156.
23. Brown, A. M. 1967. Cardiac sympathetic adrenergic pathways in which synaptic transmission is blocked by atropine sulfate. J. Physiol. (London). 191: 271.

24. Benfey, B. G. 1961. Cardiovascular actions of phenoxybenzamine. Brit. J. Pharmacol. 16: 6 .

25. Benfey, B. G. 1962. Effect of phenoxybenzamine on vagal inhibition of the heart. Can. J. Biochem. Physiol. 40: 1457.

26. Linegar, C. R., J. M. Dille, and T. Koppanyi. 1936. Studies on barbiturates. XVIII. Analysis of a peripheral action of barbiturates. J. Pharmacol. Exp. Ther. 58: 128.

27. Lang, K. F., and T. N. James. 1969. Vagal blocking action of phentolamine and dibenzyline studied by direct perfusion of the sinus node. Proc. Soc. Exp. Biol. Med. 130: 121 .

28. Berkowitz, W. D., B. J. Scherlag, E. Stein, and A. N. Damato. 1969. Relative roles of sympathetic and parasympathetic nervous systems in the carotid sinus reflex in dogs. Circ. Res. 24: 447.

29. Boss, J., and J. H. Green. 1956. The histology of the common carotid baroceptor areas of the cat. Circ. Res. 4: 12 . 